logical science by publishing books and articles on recent advances made in this field of research.

At present there are only two of us working in the Laboratory, a young doctor of medicine and myself. We are expecting a third, a bacteriologist, to come from the United States, where he has heen sent by the Rockefeller Foundation for special training. There are also several young men, now university students, whom the Laboratory hopes eventually to appoint to its staff. The problems at present being studied deal with the morphogenesis of the mammalian gonad, primarily of the germ cells, and with the gonadotrophic function of the pituitary gland.

The long years of war and occupation were a heavy blow to science in Yugoslavia. All research work was brought to a standstill. Completely shut off from the rest of the world, lacking even the most essential equipment for carrying on research, the small number of Yugoslav biologists, even if left alone by the enemy authorities (some were killed or imprisoned), were obliged to struggle for the bare necessities of life for themselves and their families. Since the War has ended, great efforts have been made to pick up the broken threads. But even now there are many obstacles. There is a shortage of almost every article essential to a research laboratory, great difficulties are encountered in replenishing depleted stocks, and reserve parts of precision apparatus are hard to get. Trained laboratory technicians are few, and so are electricians and mechanics acquainted with laboratory apparatus. We are also in dire need of technical books, journals and reprints of scientific papers. We would welcome reprints covering every field of biology and medicine, and the Laboratory at Novi Sad will be glad to forward them where they are most needed.

\section{THE CHEMICAL SOCIETY'S CENTENARY EXHIBITION}

$\mathrm{T}$ $\mathrm{HE}$ exhibition at the Science Museum, arranged as part of the centenary celebrations of the Chemical Society, was a memorable one. For the first time, through the co-operation of the director of the Museum, Dr. H. Shaw, a comprehensive display of exhibits illustrating the progress of chemistry in Britain over the past hundred years was housed under one roof.

The exhibition, organised on behalf of the Chemical Society and the XIth International Congress of Pure and Applied Chemistry, by a committee under the chairmanship of Sir Robert Robertson, was divided into two parts, illustrating the history and the everyday uses of chemistry. The historical side was arranged under ten headings each dealing with a section of the subject. Each section has been in the care of a panel of experts responsible for the selection of the exhibits, and for the corresponding chapter of the handbook to the exhibition. This handbook, "Chemical Progress" (London: H.M. Stationery Office. 1s. 6d. net), is a brief yet comprehensive survey of the British contribution to the science, which future students of chemistry may consult as a historical guide. The chairmen of the panels were Dr. A. E. Alexander, Dr. G. M. Bennett, Prof. J. D. Bernal, Prof. H. V. A. Briscoe, Dr. E. M. Crowther, Prof. C. W. Davies, Prof. D. H. Hey, Prof. C. N. Hinshelwood, Prof. E. K. Rideal, Prof. N. V. Sidgwick and Prof. M. W. Travers. The reports have been edited by Dr. F. Sherwood Taylor, curator of the Museum of the History of Science, Oxford.

A modern section dealing in a popular manner with "Chemistry in Everyday Life" was prepared by the Department of Scientific and Industrial Research, with the co-operation of the Agricultural Research Council, several research associations, and a number of industrial firms. The Central Office of Information prepared the layout of this part of the exhibition, which surveyed such fields as agriculture and food, health, homes and building, fuels, oil, transport and engineering. A popular account of this side was written by Dr. J. P. Lawrie, and this forms the second section of the handbook.

The exhibition was opened on July 14 by the president of the Chemical Society, Prof. C. N. Hinshelwood. The Minister of Education, Mr. George Tomlinson, was in the chair and welcomed the visitors. Prof. Hinshelwood in his opening speech said that the real adventures of science took place in the minds of men, and that much of the exhibition's interest would rely on the association of the objects to be seen with the men who used them.

It is impossible to do justice in the space of a short article to the many exhibits. In each branch of the subject the development was traced from the early pioneers. It was Faraday whose genius laid the foundations of so much of modern chemistry, His work on the alloys of steel was illustrated, as was that on the liquefaction of gases, the forerunner of all later researches in this field. His discovery of benzene was the start of modern organic chemistry, which was illustrated in all its aspects. His work on electrolysis has produced the modern science of electrochemistry, and the use of platinum as a catalyst. The visitor could also see, side by side with their more modern counterparts and developments, his samples of optical glass and colloidal gold.

Graham, too, the first president of the Chemical Society, was a pioneer whose experiments with simple apparatus led to the enunciation of the laws of diffusion in gases and liquids, and to the foundation of modern colloid science. The study of chemical reactions has increased our knowledge of molecular properties and brought about such material advances as photography and plastics. The early theories of valency and atomic structure put forward by New. lands and Crookes were demonstrated. These pointed the way for Mendeléeff, and also for Moseley, whose apparatus and ferrocyanide crystal were exhibited. In the range of inorganic chemistry the fundamental work of Dalton was illustrated by his diagrams of molecular structure. Near this were shown such diverse subjects as glass, precious metals, fluorine chemistry and fluorescent lighting, all items in which British chemists have played a decisive part.

The study of crystallography was represented by a large number of structural models and apparatus illustrating the development of theory and technique in this subject.

The important subject of agricultural chemistry, in which the early work of Lawes and Gilbert at Rothamsted pointed the way to modern scientific methods of increasing the fertility of the soil, was also given prominence.

It is, however, the organic chemist whose work offers the biggest variety of subjects. Each was illustrated by charts and specimens to show the structure, historical synthesis and applications of the substance. Individual exhibits showed early work in carbohydrates at St. Andrews and at Birmingham. 
The development of synthetic dyestuffs and fibres was well represented, and space was given, to name a few examples, to synthetic drugs and chemotherapeutic substances including penicillin, and to British work on the vitamins.

The historical part of the exhibition was concluded by a small exhibit of British developments in analytical chemistry.

Space forbids a description of the attractive section on "Chemistry in Everyday Life", which explained in simple terms, by means of a series of illuminated screens and diagrams, the operations and processes by which the raw materials of the laboratory are turned into finished products.

It must be regretted that a historical exhibition on this scale cannot take a permanent place in the national collections, and it is to be hoped that when the Science Museum eventually obtains its longneeded extensions, an enlarged collection, on the lines of the exhibition which has just closed, may be reassembled.

\section{CLIMATIC FLUCTUATIONS AND VEGETATION GROWTH IN NORTHERN FINLAND DURING 1890-1939}

$\mathrm{F}$ IG. 1 shows the annual variations in the growth in 4 diameter of pine (Pinus silvestris L.) near the timber line in the extreme north of Finland, at about lat. $69^{\circ} 30-70^{\circ} \mathrm{N}$. The diagram is based on two series of figures ${ }^{1}$ : $(a)$ represents the weighted average of 148 increment cores collected in July 1939 and 1940 ; (b) represents the average of 58 increment cores collected in July 1945.

The diagram shows the great variation from year to year in the production of organic matter, in this case cellulose. We observe, moreover, an obvious 'low' period of growth during 1901-16, and the gradually increasing growth during the 1920's.

The timber-line forest is very susceptible to the smallest changes in climate (cf. the general statements by Griggs ${ }^{2}$ and by Hustich ${ }^{3}$ ). Thus Fig. 1 may perhaps illustrate to some extent the general influence on growth in the northern part of the Eurasian coniferous zone of the most recent climatic
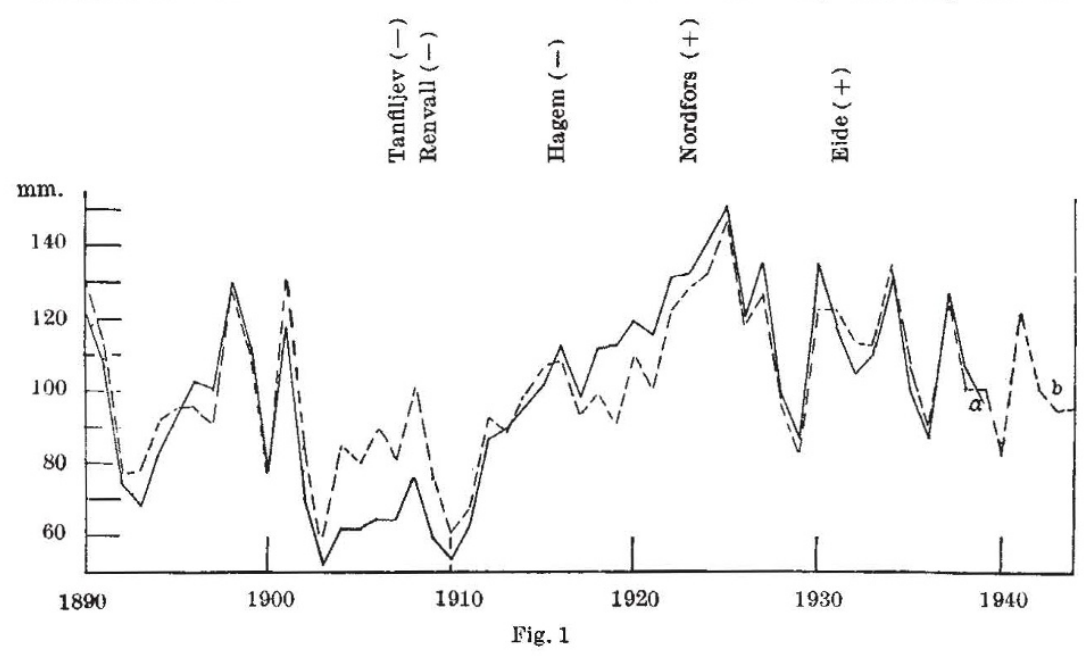

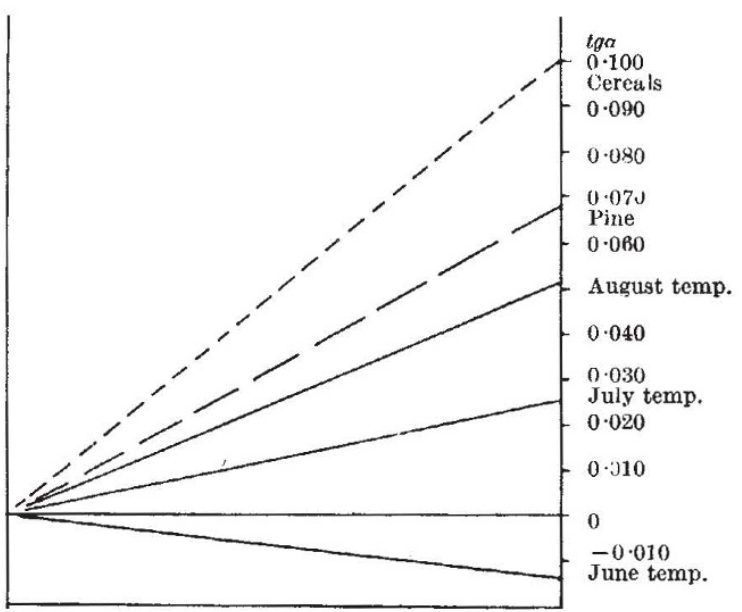

Fig. 2. THE $t g \alpha$-CORFFICIENTS OF TEMPERATURE, CROP AND GROWTH (PINE) SERIES 1890-1939 ON AN EXAGGERATED SCALE. THE

changes. The names on the diagram are those of scientific workers who have expressed an opinion about the regression or progression of the timberline. The signs - or + indicate that the author mentioned believed it to be receding or advancing respectively. Their opinions are reasonably well explained when considered in connexion with this cyclical growth curve. We can easily understand, for example, why Renvall', who worked in the 'low' period, demanded rigorous protection of the timberline forest because of the "regression of the timber line" ; and just as readily we understand why Eide ${ }^{5}$, who worked in the 'good' period, was of quite another opinion. I think that the work of Russian scientific investigators on this subject during the same period would give a similar result. The 'low' period is also evident from the occurrence of seed years; there was no important seed year during the 'low' period, shown in Fig. 1, in the northernmost pine forests of Finland.

The same cyclical variation in the production of organic matter also appears in the crop variations of rye, barley, oats and potatoes in northern Finland. The positive trend or 'progression' in the period 1890-1939 is still more pronounced. The positive influence of the climatic improvement of the 1920's was, so far as cereals are concerned, over-accentuated by the improvement in cultivation methods in Finland in recent decades, and by the introduction of better varieties of the various cereals.

In the accompanying table some information is given on the trend (the $\operatorname{tg} \alpha$ coefficient of the series during $1890-$ 1939) of some temperature indicators, and also of some crop-yield series and growthseries of pine (curve $a$ in Fig. 1). The influence of precipitation on growth in the far north is, as is known, of minor significance.

We find that the June temperature shows a slight negative trend, but the July temperature, and especially the August temperature, 